\title{
A long time ago in a galaxy far, far away... How microfinance evolved and how research followed
}

\author{
Marek Hudon, Marc Labie and Ariane Szafarz
}

This article is the introductory chapter of the book A Research Agenda for Financial Inclusion and Microfinance, edited by Marek Hudon, Marc Labie and Ariane Szafarz, and forthcoming in 2019 with Elgar Research Publishing. This introductive article written by the editors explains how research in microfinance and financial inclusion evolved together with field practices. It identifies the four periods in the life of the microfinance sector that match four steps in research development: genesis, childhood, adolescence, and maturity. The article discusses whether this evolution could lead to a decline. Finally, it presents the monograph, which is organized along thematic groups of chapters. The titles of the four parts of the book are: "Framing research on microfinance and financial inclusion," "Social, environmental and financial performance," "Targets for financial inclusion," and "Institutional and technological design." Each chapter is written by scholars whose expertise on financial inclusion and microfinance is recognized internationally.

Keywords: Microfinance, microcredit, financial inclusion, development, social finance.

JEL Classifications: G21, G23, O16, G32, O19, B55.

\author{
CEB Working Paper No 19/013 \\ May 2019
}




\title{
A long time ago in a galaxy far, far away...
}

\section{How microfinance evolved and how research followed}

\author{
Marek Hudon, Marc Labie and Ariane Szafarz ${ }^{1}$
}

\begin{abstract}
This article is the introductory chapter of the book A Research Agenda for Financial Inclusion and Microfinance, edited by Marek Hudon, Marc Labie and Ariane Szafarz, and forthcoming in 2019 with Elgar Research Publishing. This introductive article written by the editors explains how research in microfinance and financial inclusion evolved together with field practices. It identifies the four periods in the life of the microfinance sector that match four steps in research development: genesis, childhood, adolescence, and maturity. The article discusses whether this evolution could lead to a decline. Finally, it presents the monograph, which is organized along thematic groups of chapters. The titles of the four parts of the book are: "Framing research on microfinance and financial inclusion," "Social, environmental and financial performance," "Targets for financial inclusion," and "Institutional and technological design." Each chapter is written by scholars whose expertise on financial inclusion and microfinance is recognized internationally.
\end{abstract}

\footnotetext{
${ }^{1}$ Marek Hudon is in the Solvay Brussels School of Economics and Management at CERMi-Université Libre de Bruxelles, Marc Labie is in the Warocqué School of Business and Economics at CERMi-Université de Mons and Ariane Szafarz is in the Solvay Brussels School of Economics and Management at CERMi-Université Libre de Bruxelles, Belgium.
} 


\section{A long time ago in a galaxy far, far away...}

\section{How microfinance evolved and how research followed}

For a long time already, scholars and practitioners have questioned the link between economic development and the financial sector. Undeniably, there is a deep connection there, but causalities are hard to capture, and are therefore controversial. Arguably, causal links exist in both ways depending on the precise variables considered. In brief, whether the development of the financial sector follows economic development, or the reverse, is a key issue when it comes to drafting policy recommendations for development aid. This book focusses on the segment of the financial sector that affects the situation of the unbanked and marginalized people. By bringing together original and multidisciplinary contributions from world-renowned scholars in the field, it has the ambition of providing the readers with an up-to-date state of the art on key issues of research in microfinance and financial inclusion. In line with the editorial policy of the series, each chapter also opens avenues worth exploring in future academic work. This introductive chapter explains how the issues addressed in this volume issues emerged from the field. Next, we describe the plan of the monograph and briefly evoke a few promising topics left aside to fulfill space constraints.

Contemporary microfinance appeared in the 1970s, when it appeared that injecting capital through development banks was not the universal cure for poverty (Hulme and Mosley, 1996). At the same time, the ideological context was favorable. The 1980s have witnessed a strong political push in favor of deregulating markets, stimulating private enterprises, and favoring as much competition as possible (Weber, 2004). This was fertile ground for the development of microfinance institutions. First, microfinance carried the great hope that subsidies would make it 
possible to design organizations financing excluded people turned into micro-entrepreneurs. Their private businesses would generate additional incomes, leading to significantly improving their livelihoods. In a nutshell, poverty understood as a lack of income could be solved by microcredit, which allowed the poor to work their own way out of poverty. Second, microfinance was built on a promise that microfinance institutions (MFIs, as they got called) would break even after a few years and provide financial inclusion to more and more people (Morduch, 1999a). The accuracy of this past prediction is still open to discussion. While, undeniably, microfinance has undergone a tremendous development during the last three decades, leading to more financial inclusion than ever, several original assumptions were severely confronted with reality. First, microcredit does not necessarily generate income through entrepreneurial activities since part of it is used for consumer loans. Second, the initial target pool of borrowers, made up of the poorest of the poor, is hard to reach. Last, the objective of smoothing the impact of economic shocks appeared to be more limited than expected.

Over time, microfinance grew into a self-standing industry connected simultaneously to the development community and to the financial world (Brière \& Szafarz, 2015). The sector experienced, however, a pendulum movement. At first, the idea of microcredit was strange to many who believed that if lending to the poor was a feasible business, it would already have existed for long. Next, the idea became an attractive but marginal success story, which eventually turned into a true promise that would soon be considered as a major innovation that could change the world. Microfinance pioneers and leaders were widely acknowledged. In about 15 years, between 1990 and 2005, microfinance became the flagship of development finance and a poster 
child for social enterprises and social entrepreneurship, such as the Ashoka network ${ }^{2}$ of social entrepreneurs. In 2006, Muhammad Yunus and the Grameen Bank were awarded the Nobel Peace Prize. This can be seen as the peak of the international support to microfinance.

Then came the negative swing: Some harsh criticisms were legitimate by putting emphasis on over-indebtedness (Alfonso et al., 2017), on microcredit management crises in countries such as Bosnia, Morocco, and Nicaragua, and on perverse individual impacts, such as intolerable levels of peer pressure attached to some group lending practices (Guérin et al., 2015). The microfinance industry faced also moral criticism related chiefly both to the high interest rates charged and to a few much-trumpeted IPOs. In particular, the successful stock offering by the Mexican Banco Compartamos, the largest Latin American MFI (Hudon \& Ashta, 2013), attracted criticisms highlighting the perverse effet of commercialization (Hermes \& Lensink, 2011; Hudon and Sandberg, 2013). Simultaneously, new impact studies showed that microcredit were having a limited effect (Karlan and Zinman, 2009; Augsburg et al., 2015; Banerjee et al., 2015). The discouraging trend pushed some historical microfinance actors to move away from the sector and head towards new ventures.

Today, the pendulum makes smaller moves and the microfinance community is becoming more nuanced. Meanwhile, the industry has evolved too. Its original single-product focus on microcredit has given way to a larger scope of financial services including micro-savings and micro-insurance. This move explains why the leading terminology became "microfinance" rather than "microcredit." Currently, however, many scholars use the "financial inclusion" denomination that signals an agenda redrafting in the wake of the harsh criticism about limited

2 The Ashoska network brings international attention on social ventures. It is active in 93 countries and has over 3,000 fellows worldwide (see https://www.ashoka.org/en consulted on 11 November 2018). 
impact. According to this view, the real purpose of microfinance is to provide financial inclusion (Servet, 2011; Roodman, 2012). For better or for worse, a lot has been learned in the last 40 years about financial services for the poor and the unbanked. But a lot more remains to be imagined or discovered for the financial sectors to play a decisive role in development policies.

Looking back in time, we identify four periods in the history of microfinance and financial inclusion. These periods match roughly the four main research steps in the field. First, the genesis in the 1970 s and 1980 s was the period when microcredit was monopolizing public attention. Microcredit was first developed in Asia and Latin America for income-generating activities only, with the clear goal of helping the poor to get out of poverty thanks to their own efforts. Subsidies to this emerging industry were considered legitimate but due to disappear over time. Profits were promoted only to prove that breaking-even was feasible. Many schemes and organization set-ups were tested for granting credit, ranging from traditional nongovernmental organizations (NGOs) to self-help groups and cooperative banks related to an association, such as SEWA in India. Creativity was welcome, and expectations were huge.

During the genesis step, the scholarly literature focused on the economic fundamentals explaining that microcredit was filling a market gap, and how this young industry would address the credit rationing faced by the poor (Adams et al., 1984). Even though informal moneylenders fulfilled some financial needs of their clientele, they were unable to provide the same services as formal institutions do (Christen, 1989). Articles also discussed the optimal design of replicable organizations ensuring the steady growth to match the needs of the under-served populations. Most of the research was thus giving the broad outlines of what microcredit could do, including group lending with joint liability, collateralization options, and screening technology, to name a few (Adams, 1988). 
The second period, taking place in the 1990s and the early 2000s, represented the childhood of microfinance. The industry structured itself and started realizing that the original storytelling did not match field experience perfectly. The needs of poor people went beyond microcredit. This period saw a tremendous growth in microfinance activities: MFIs were established all over the world, often through networks, such as the ACCION network, Finca and WWB. The attitude of public authorities moved typically from reluctance to support. Meanwhile, new actors appeared, including international forums, rating agencies, microfinance investment vehicles, and credit bureaus. "Best practices" were identified and new services, such as micro-savings and money transfers, were developed, so triggering standardization of both practices and institutional designs. Yet, structural limitations and differences in local customs and legal frameworks tempered the standardization impulse. Flagship NGOs transformed themselves into regulated shareholder firms: Bolivia's Bancosol in 1992, Kenya's K-REP in 1998 (Campion \& White, 1999). Overall, in the second period, the microfinance supply was massified, but new constraints emerged.

On the scholarly side, the childhood phase was characterized by more attention being dedicated to institutional issues, such as the dependence on subsidies, the trade-off between social and financial goals, corporate governance features, and public policies issues (Morduch, 1999b). The methodological contributions tackled the various measures to be used for assessing the development of the existing organizations, be it social or financial. The common denominator was the concern for the so-called "double bottom line" that is part of the DNA of microfinance.

$<$ line space $>$ 
Third, the teenager step in the late 2000s was the time of disillusions: The microfinance supply was perceived as too tight to meet well the demand for financial services likely because the products were too standardized for the populations they are supposed to help (Canales, 2013). Large randomized control trials revealed that the impact of microfinance was disappointing (Bauchet et al., 2011; Duvendack et al., 2011). Not only was empowerment lower than expected, but also bad outcomes, such as over-indebtedness, were sometimes observed (Fouillet \& Augsburg, 2010; Guérin et al., 2015). The transformation towards regulated and monitored institutions intensified (D’Espallier et al., 2017): Some MFIs were established as, or became, fullservice microbanks, others benefitted from the status of non-banking financial institutions, which collect savings. Meanwhile, full-blown crises occurred either at the institution level, or at the country level. Voices expressed their concern of mission drift characterized by MFIs shifting from social to financial priorities. The early days of innocence were gone.

Teenagers question and oppose established rules. There is no doubt that such a movement took place in the microfinance literature. The main research outcomes of the third period are those bringing criticisms to the field. Impact studies showed the limits of poverty alleviation by providing microfinance products only. Articles uncovered discriminatory biases against disabled borrowers and ambitious businesswomen (Agier \& Szafarz, 2013; Labie et al., 2015) and low interest for rural development (Bastiaensen \& Marchetti, 2011). While women's empowerment was a key motivation for the development of early microfinance, deeper analyses revealed that the empowerment mantra of lending to women was often leading to female indebtedness associated with male control over debt use. Most importantly, the formal concept of mission drift emerged (Armendáriz \& Szafarz, 2011; Mersland \& Strøm, 2010). 
The fourth period is maturity, the state in which most of the industry is standing nowadays. But is it maturity or decline? History will tell, at least it is the time for nuances. The need for financial innovation to serve the poor is gaining momentum, notably through mobile banking. The balance between flexibility — in products and procedures — and discipline - in repayment - receives more attention (Laureti et al., 2017). Accordingly, consumer protection is developed by a variety of initiatives, such as the Smart Campaign which aims at uniting "financial leaders around a common goal: to keep clients as the driving force of the industry" (Smart Campaign). ${ }^{3}$ The debate on impact is moving from truth-telling discourses for or against randomization to more nuanced arguments (Cull et al., 2018; Hermes \& Hudon, 2018; Abramowicz \& Szafarz, 2018). The risk of mission drift for double-bottom line institutions is addressed, leading to an open debate on the limits of commercialization. In a nutshell, the sector is still growing but the actors acknowledge its diversity, its contingencies, and ultimately its limits.

Even historical players have diversified their activities and favor the broader agenda of "social business." Examples of this shift include Yunus' partnerships with multinational corporations, and CERISE $^{4}$ applying its social-performance evaluation toolkit to a larger class of social businesses. Likewise, IPC/ProCredit in Germany started focusing on SME lending and targeting the "missing middle" that is the gap between microfinance and traditional banking. The Microcredit Summit Campaign (2012) captured for the first time a decrease in the number of clients served by microfinance institutions. Even though most players are still motivated and have remained in the sector and are convinced of their utility, enthusiasm has dwindled. At the same

\footnotetext{
${ }^{3}$ https://www.smartcampaign.org (consulted on 11 November 2018)

4 CERISE is a network of French organizations (CIDR, GRET, IRAM, IRC/SupAgro, and CIRAD) established in 1998 to support shared microfinance R\&D initiatives.
} 
time, the number of scholarly articles on microfinance stopped growing (Gutiérrez-Nieto \& Serrano-Cinca, 2018).

With maturity, the microfinance literature is ever more merging with mainstream literature be it in economics, management, finance, or sociology. MFIs are often presented as fruitful examples of social enterprises or hybrid organizations, fit for applications of innovative theories linked to organizations with multiple bottom lines. Microfinance research can evidently serve this purpose. However, scholars wishing to address the frontiers of financial inclusion have to come back to basics and find out how flexibility in credit and deposit products can be provided without jeopardizing institutional stability, how the industry should be regulated and supervized, and ultimately how to combine actions in order to trigger social impact. In a nutshell, the focus shifted from poverty alleviation to financial inclusion of the largest number of people in need, in order to benefit them and society as a whole. This shift gives the impression that microfinance is justified mainly by its ability to address one core discrimination: financial exclusion or the lack of access to financial services (Labie et al., 2015). Yet, calling for public subsidization and private donations to microfinance requires legitimization through clear-cut social impact. Rather than poverty alleviation, Morduch (2011) suggests that microfinance helps the unbanked facing irregular and insecure streams of income by giving them tools for liquidity management. By extending access to banking/insurance products to the disadvantaged populations, financial inclusion strengthens their capacity to sustain adverse financial shocks. At the same time, the social missions of a significant proportion of MFIs remain primarily poverty alleviation, women's empowerment, or rural development. 
Research on microfinance is being produced by scholars from various fields, such as economics, finance, management, sociology, political science, and anthropology. All of them have broadened the scope by studying microfinance practices, institutions, and markets as complex objects with multiple angles. In our opinion, time has come to confront their findings by adopting a transdisciplinary perspective. But stepping outside of one's comfort zone can be painful. Therefore, an important objective of this book is to help the readers making the first step in the direction of transdisciplinary research on microfinance. To achieve this purpose, we asked experts from different disciplines to give their vision of key issues on microfinance and financial inclusion and identify top priorities for future research.

The book is comprised of four parts. The first, titled "Framing Research on Microfinance and Financial Inclusion," contains four contributions that together draw a big picture representing the current state of the art on microfinance and financial inclusion. This part of the book is intended to put into perspective how microfinance conversations participate in the most recent global and critical reflections on what economists, such as Jonathan Morduch and Timothy Ogden, call social enterprise, and management scholars, Brian Hathaway and Tyler Wry, call hybrid organizations. The complementary views brought by these two chapters point to the importance of gauging the real impact of microfinance as presented in Maren Duvendack's chapter. Isabelle Guérin, Solène Morvant-Roux and Jean-Michel Servet complete the picture by discussing the limits of normative approaches to financial practices. 
The second part, "Social, Environmental and Financial Performance" focusses on the assessment of multi-purpose MFIs, which target social, financial and sometimes environmental bottom-lines. Bert D'Espallier and Jann Goedecke present how social performance is measured in microfinance. They warn us against the apparently benign limitations of common proxies. Johan Bastiaensen, Frédéric Huybrechs, and Gert Van Hecken elaborate on how microfinance and financial inclusion can contribute to environmental sustainability. Valentina Hartaska and Denis Nadolnyak offer an overview of efficiency and productivity analyses in microfinance.

The third part, "Targets for Financial Inclusion," is devoted to financial inclusion in various contexts. Laurent Weill explains the potentials and limits of Islamic microfinance. Adriana Garcia and Robert Lensink discuss the merits of "microfinance plus," an expression referring to the joint offer of financial and non-financial services to the poor. The corresponding maximalist approach of microfinance challenges the minimalist approach limited to financial services only. Anastasia Cozarenco and Ariane Szafarz present a nascent industry flourishing in industrialized countries, also known as "microfinance in the North," connecting the microfinance niche to the broader context of social finance.

The fourth and final part of this volume, "Institutional and Technological Design," scrutinizes the institutional and technological features of modern microfinance. Roy Mersland, Stephen Zamore, Kwame Ohene Djan, and Tigist Woldetsadik Sommeno review the internationalization of the microfinance industry. Niels Hermes addresses the issue of governance with a special attention to boardrooms dynamics. Last but not least, financial technology (fintech) has gained recently a tremendous influence on financial inclusion, and much more is still to come. Baptiste Venet summarizes the state of knowledge in this promising field. 
It is with regret that, for space and contingency constraints, we had to leave aside some promising topics. By way of catching up, we provide here a short, and subjective, list of issues that, in addition to those presented by the book's contributors, could open up new horizons for research on microfinance and financial inclusion. The three topics we wish to highlight relate to women's empowerment, subsidy design, and access to financial markets.

In 2017, the Journal of Development Studies (Volume 53, Issue 5) published a collection of articles on microfinance and gender. The introductory chapter (Garikipati et al., 2017) raised an alarming bell on the dangers faced by the promise of women's empowerment through microfinance. As Duflo (2012, p. 1076) puts it: “economic development alone is insufficient to ensure significant progress in important dimensions of women's empowerment." The evolution of microfinance toward commercialization and marketization has coincided with a decline in the concern of serving women. While some MFIs are still affirming a strong propensity of serving female clients, they become more and more the exception rather than the rule they used to be. In a recent analysis of mission statements, Mersland et al. (2018) show that only 22 percent of a sample of MFIs worldwide mention explicitly women as a specific target clientele. From a profitoriented perspective, serving women yields a trade-off since female borrowers are recognized as more trustworthy but at the same time their lower income makes them less attractive clients for providers of financial services (D'Espallier et al., 2011). Disentangling the causal effects of each arm of this trade-off on the strategic choices made by MFIs offers promising grounds for future research. While the top management of MFIs is typically male-dominated, the proportion of women in management positions is higher in MFIs than in typical banks (Périlleux \& Szafarz, 2015). Female leadership has been recognized to have a positive impact on the performance of MFIs (Strøm et al., 2014; Hartarska et al., 2014), but we still miss a large-scale study scrutinizing 
how female employees in any position, in MFIs and in other social enterprises, contribute to pushing forward the agenda of women's empowerment.

Regarding public policies, development economists have long addressed the role of subsidized credit lines offered by donors (Adams et al., 1984) and discuss specific case studies in microfinance subsidization (Morduch, 1999a) leading to the notion of smart subsidy ${ }^{5}$ (Morduch, 2006). Recent publications on public policy adopt a more comprehensive approach on the impact of subsidies on the performance of MFIs (Cull et al., 2018; D'Espallier et al., 2013). The theoretical model of Cornée et al. (2018) optimizes blended-finance strategies combining various sources of funding, including loans and grants. Hudon et al. (2018) show that the way subsidies are delivered can have long-lasting consequences on the commercialization of the receiving institution. This stream of research would be usefully extended by further work on the design of both subsidies and financial products.

Last, the connection between MFIs and capital markets is probably one of the best kept secrets. It is however worth exploring how MFIs manage to diversify their sources of funds in order to reduce their dependence on public financing. Larger MFIs tap financial markets, but we basically ignore how they make the financial decisions involving financial instruments such as MIVs, securitization, CDOs (Dorfleitner and Pribery, 2013; Dorfleitner et al., 2017). Only a handful of MFIs went public. Are they exceptions or do they indicate the way forward? This and many other questions on the topic remain open.

\footnotetext{
5"The idea of smart subsidy springs from the premise that subsidies are neither inherently useful nor inherently flawed. Rather, their effectiveness depends on design and implementation. Smart subsidies maximize social benefits while minimizing distortions and misplaced targeting" (Morduch, 2006, p. 11).
} 
The main takeaway of this introductory chapter is that microfinance has gained maturity over time, particularly over the last ten years. Meanwhile, it has morphed into the new field of financial inclusion. Innovation was a key driver of microfinance initiatives. If financial inclusion is to meet its promises, more innovation is needed, and research has a central role to play in this process. It can help avoiding pitfalls; it can help testing new ideas, and most importantly it can help understanding the real needs of the people microfinance was originally conceived for. New researchers joining the field are welcome to keep an open mind and a critical perspective, especially when it comes to addressing common wisdom on ventures with a social goal. We hope that this book will stimulate them to be part of this exciting journey.

Finally, we wish to extend our deep gratitude to all the authors who have graciously accepted our invitation to be part of this adventure. They have not only provided remarkable contributions, but also interacted kindly and efficiently with Laurie Goffette, the CERMi coordinator, and the three of us on multiple occasions. We owe a great debt to the dynamism, creativity and reliability of Laurie who provided rigorous monitoring of the editorial process and was instrumental in ensuring that this book came out. It was both a challenging experience and a great pleasure for us to edit this volume. We thank Mr. Matthew Pitman, Mr. Harry Fabian, Ms. Alexandra O'Connell, Mr. John Hewish, Ms. Sue Sharp, Ms. Megan Hylton, Ms. Veronica Mills, and the whole Edward Elgar team for having offered us this opportunity. 


\section{References}

Abramowicz, M. and Szafarz, A. (2018). Ethics of RCTs: Should economists care about equipoise? Mimeo, Université Libre de Bruxelles.

Adams, D. (1988). The conundrum of successful credit projects in floundering rural financial markets, Economic Development and Cultural Change, 36(2), 355-367.

Adams, D., Graham, D., and Von Pischke, J.D. (1984). Undermining Rural Development with Cheap Credit, Boulder: Westview Press.

Afonso, J.S., Morvant-Roux, S., Guérin, I., and Forcella, D. (2017). Doing good by doing well? Microfinance, self-regulation and borrowers' over-indebtedness in the Dominican Republic. Journal of International Development, 29(7), 919-935.

Agier, I. and Szafarz, A. (2013). Microfinance and gender: Is there a glass ceiling on loan size? World Development, 42(C), 165-181.

Armendáriz, B. and Szafarz, A. (2011). On mission drift in microfinance institutions. In The Handbook of Microfinance (pp. 341-366), World Scientific Publishing.

Augsburg, B., De Haas, R., Harmgart, H., and Meghir, C. (2015). The impacts of microcredit: Evidence from Bosnia and Herzegovina. American Economic Journal: Applied Economics, 7(1), 183-203.

Banerjee, A., Duflo, E., Glennerster, R., and Kinnan, C. (2015). The miracle of microfinance? Evidence from a randomized evaluation. American Economic Journal: Applied Economics, $7(1), 22-53$. 
Bastiaensen, J. and Marchetti, P. (2011). Rural microfinance and agricultural value chains: Strategies and perspectives of the Fondo de Desarrollo Local in Nicaragua. In Armendáriz, B. and M. Labie, The Handbook of Microfinance (pp. 461-500).

Bauchet, J., Marshall, C., Starita, L., Thomas, J., and Yalouris, A. (2011). Latest findings from randomized evaluations of microfinance, World Bank Group.

Brière, M. and Szafarz, A. (2015). Does commercial microfinance belong to the financial sector? Lessons from the stock market. World Development, 67, 110-125.

Canales, R. (2013). Weaving straw into gold: Managing organizational tensions between standardization and flexibility in microfinance. Organization Science, 25(1), 1-28.

Campion, A. and White, V. (1999). Institutional Metamorphosis: Transformation of Microfinance NGOs into Regulated Financial Institutions. MicroFinance Network.

Christen, R. (1989). What microenterprise credit programmes can learn from the moneylenders. Discussion Papers Series No. 4, Cambridge, MA: ACCION International.

Cornée, S., Jegers, M., and Szafarz, A. (2018). A theory of social finance. CEB Working Paper 18-010, Université Libre de Bruxelles.

Cull, R., Demirgüç-Kunt, A., Morduch, J. (2018). The microfinance business model: Enduring subsidy and modest profit. World Bank Economic Review, 32(2), 221-244.

D’Espallier, B., Guérin, I., and Mersland, R (2011). Women and repayment in microfinance: A global analysis. World Development, 39(5), 758-772. 
D’Espallier, B., Hudon, M., and Szafarz, A. (2013). Unsubsidized microfinance institutions. Economics Letters, 120(2), 174-176.

Dorfleitner, G. and Priberny, C. (2013). A quantitative model for structured microfinance. Quarterly Review of Economics and Finance, 53(1), 12-22.

Dorfleitner, G., Röhe, M., and Renier, N. (2017). The access of microfinance institutions to debt capital: An empirical investigation of microfinance investment vehicles. Quarterly Review of Economics and Finance, 65, 1-15.

Duflo, E. (2012). Women empowerment and economic development. Journal of Economic Literature, 50(4), 1051-1079.

Duvendack, M., Palmer-Jones, R., Copestake, J. G., Hooper, L., Loke, Y., and Rao, N. (2011). What is the evidence of the impact of microfinance on the well-being of poor people? EPPI-Centre, Social Science Research Unit, Institute of Education, University of London.

Fouillet C. and Augsburg B. (2010). Profit empowerment: The microfinance institution's mission drift, Perspectives on Global Development and Technology, 9(3-4), 323-351.

Garikipati S., Guérin, I., Johnson, S., and Szafarz, A. (2017), Microfinance and gender: Issues, challenges and the road ahead. Journal of Development Studies, 53(5), 641-648.

Guérin, I., Labie, M., and Servet, J.M. (eds), (2015). The Crises of Microcredit. Zed Books, London, 207 pages.

Gutiérrez-Nieto, B. and Serrano-Cinca, C. (2018), 20 years of research in microfinance: A scientometric approach, Paper presented at the 2018 CERMi research day, Brussels. 
Hartarska, V., Nadolnyak, D., and Mersland, R. (2014). Are women better bankers to the poor? Evidence from rural microfinance institutions. American Journal of Agricultural Economics, 96(5), 1291-1306.

Hermes, N. and Hudon, M. (2018). Determinants of the performance of microfinance institutions: A systematic review. Journal of Economic Surveys, 32(5), 1483-1513.

Hermes, N., and Lensink, R. (2011). Microfinance: its impact, outreach, and sustainability. World Development, 39(6), 875-881.

Hudon, M. and Ashta, A. (2013). Fairness and microcredit interest rates: From Rawlsian principles of justice to the distribution of the bargaining range. Business Ethics: A European Review, 22(3), 277-291.

Hudon, M. and Sandberg, J. (2013). The ethical crisis in microfinance: Issues, findings, and implications. Business Ethics Quarterly, 23(4), 561-589.

Hudon, M., Reichert, P., and Szafarz, A. (2018). Crowding-in or crowding-out: Subsidy design as a strategic device to foster commercialization. Mimeo, Université Libre de Bruxelles.

Hulme, D. and Mosley, P. (1996). Finance Against Poverty (Vol. 1). Routledge, London.

Karlan, D. and Zinman, J. (2009). Expanding credit access: Using randomized supply decisions to estimate the impacts. Review of Financial Studies, 23(1), 433-464.

Labie, M., Méon, P.G., Mersland, R., and Szafarz, A. (2015). Discrimination by microcredit officers: Theory and evidence on disability in Uganda. Quarterly Review of Economics and Finance, 58, 44-55. 
Laureti, C., De Janvry, A., and Sadoulet, E. (2017). Flexible Microfinance Products for Financial Management by the Poor: Evidence from SafeSave, WP-CEB 17-036, Université Libre de Bruxelles.

Mersland, R. and Strøm, R.Ø. (2010). Microfinance mission drift? World Development, 38(1), $28-36$.

Mersland, R., Nyarko, S.A., and Szafarz, A. (2018). Do social enterprises walk the talk? Assessing microfinance performances with mission statements. Mimeo, Agder University and Université Libre de Bruxelles.

Morduch, J. (1999a). The microfinance promise. Journal of Economic Literature, 37(4), 15691614.

Morduch, J. (1999b). The role of subsidies in microfinance: Evidence from the Grameen Bank. Journal of Development Economics, 60(1), 229-248.

Morduch, J. (2006), Smart Subsidies, Journal of Microfinance/ESR Review, 8(1), 10-17.

Morduch, J. (2011). Why finance matters. Science, 332(6035), 1271-1272.

Périlleux, A. and Szafarz, A. (2015). Women leaders and social performance: Evidence from financial cooperatives in Senegal. World Development, 74, 437-452.

Roodman, D. (2012). Due Diligence: An Impertinent Inquiry into Microfinance. CGD Books.

Servet, J.M. (2011). Corporate responsibility versus social performance and financial inclusion. In The Handbook of Microfinance (pp. 301-322), World Scientific Publishing. 
Strøm, R.Ø., D’Espallier, B., and Mersland, R. (2014). Female leadership, performance, and governance in microfinance institutions, Journal of Banking and Finance, 42, 60-75.

Weber, H. (2004). The 'new economy' and social risk: Banking on the poor? Review of International Political Economy, 11(2), 356-386. 